\title{
Photosynthetic response and zonation of three species of Gelidiales from Tenerife, Canary Islands
}

\author{
by \\ S. Domínguez-Álvarez', J.M. Rico² \& M.C. Gil-Rodríguez ${ }^{1}$ \\ ${ }^{1}$ Departamento de Biología Vegetal (Botánica), Universidad de La Laguna, E-38071 La Laguna, Spain. \\ ${ }^{2}$ Departamento de Biología de Organismos y Sistemas, Universidad de Oviedo, E-33071 Oviedo, Spain. jmrico@uniovi.es
}

\begin{abstract}
Domínguez-Álvarez, S., Rico, J.M. \& Gil-Rodríguez, M.C. 2011. Photosynthetic response and zonation of three species of Gelidiales from Tenerife, Canary Islands. Anales Jard. Bot. Madrid 68(1): 117-124.

Three species of Gelidiales (Gelidium arbuscula, Gelidium canariense and Pterocladiella capillacea) (Rhodophyta) were selected due to their abundance in the marine lower intertidal of the north coast of the island of Tenerife (Canary Islands), to assess, using PAM fluorescence, the importance of irradiance and exposure to air on vertical distribution. We compared tolerance to emersion by air-drying fronds under simulated emersion, and results suggest that recovery of photosynthesis after emersion plays a major role in the vertical distribution of these three species. Morphological traits such as clumped fronds explain the higher tolerances, and reduced water loss of the species upper on the shore. Local differences between sites may be related to slight differences in the light regime related to topography.
\end{abstract}

Keywords: Canary Islands, ecophysiology, Gelidiales, Gelidium, photosynthesis, Pterocladiella.

\section{Introduction}

Zonation of seaweeds is the most conspicuous characteristic of rocky shores worldwide (Lewis, 1964; Stephenson \& Stephenson, 1972; Pérès, 1982). Algal zonation seems to be due to several causes acting simultaneously, but the relative contribution of each factor is under debate. Thus, inter-specific competition has usually been the consensus for the main cause of zonation (Chapman, 1973, 1974). However, experimental studies propose that physiological limits of seaweeds are also involved in zonation (Dring \&

\section{Resumen}

Domínguez-Álvarez, S., Rico, J.M. \& Gil-Rodríguez, M.C. 2011. Respuestas fotosintéticas y zonación de tres especies de Gelidiales de Tenerife, Islas Canarias. Anales Jard. Bot. Madrid 68(1): 117-124 (en inglés).

Se han seleccionado tres especies de Gelidiales (Gelidium arbuscula, Gelidium canariense y Pterocladiella capillacea) que son abundantes en los niveles inferiores del intermareal de la costa $N$ de Tenerife para establecer, utilizando fluorescencia tipo PAM, la importancia de la cantidad de luz y la exposición al aire en su zonación vertical. Se ha comparado la tolerancia a la emersión en frondes expuestas al aire, y los resultados sugieren que la capacidad de recuperación de la fotosíntesis tras la emersión tiene un papel fundamental en la explicación de la posición vertical de estas tres especies. Además, características morfológicas como el apelotonamiento de las frondes pueden coadyuvar a la mayor tolerancia, al reducir la pérdida de agua en emersión en las especies de niveles más altos. Las variaciones entre sitios se pueden deber a desigualdades locales en la cantidad de luz provocadas por diferencias topográficas.

Palabras clave: ecofisiología, fotosíntesis, Gelidiales, Gelidium, Islas Canarias, Pterocladiella.

Brown, 1982; Rico \& Fredriksen, 1996; Wiencke \& al., 2000; Bischof \& al., 2006).

Intertidal seaweeds are exposed to rhythmic emersion and submersion periods. The dehydration of algal thalli during the emersion imposes very stressful conditions and it has been supposed that the recovery of photosynthesis after emersion could be a factor involved in the zonation pattern of seaweeds. For example, the recovery of photosynthesis of brown algae, after desiccation during the low tide, was correlated with their heights in the zonation of European shores (Dring \& Brown, 1982). A similar correlation 
was argued for the zonation pattern of different species in Gelidiaceae in N Iberian Peninsula (Rico \& Fredriksen, 1996). However, more experimental studies are needed/required to improve our knowledge the relationship between photosynthetic performance of intertidal algae and their heights in the zonation pattern.

It is also known that dynamic photo-inhibition of photosynthetic quantum yield (Hall \& Rao, 1999) occurs in seaweeds exposed to high levels of irradiance at noon, but such photo-inhibition is more important the lower in the zonation that the species occurs. Thus, although a very low level of photo-inhibition was detected in the red alga Rissoella verruculosa growing in the upper intertidal (Flores-Moya \& al., 1998) photoinhibition is more important in seaweeds from the lower part of the intertidal (Huppertz \& al., 1990; Hanelt \& al., 1993); moreover, the reduction of photosynthesis was very high in a subtidal species transplanted close to sea surface (Gevaert \& al., 2002).

The tides that affect the coasts of the Canaries are of semidiurnal character, with highest high waters that do not surpass $3 \mathrm{~m}$ above Lowest Astronomical Tide (LAT), whereas the lowest low tides reach, occasionally, values of $0 \mathrm{~m}$. The steep northern coast of the island of Tenerife is very exposed, and this constitutes one of the most decisive factors determining the species composition of the lower intertidal vegetation that is formed, characteristically, by species that tolerate big swell. In these lower intertidal and shal- low subtidal environments, three species of Gelidiales form successive belts. The upper one is an intense red colour, dominated by Pterocladiella capillacea (S.G. Gmelin) Santelices \& Hommersand; then P. capillacea is progressively substituted by Gelidium arbuscula Bory de Saint-Vincent ex Børgesen (around 0.7-0.8 $\mathrm{m}$ above LAT). Below it there is a wide belt, reaching the upper subtidal, darker in colour, dominated by Gelidium canariense (Grunow) Seoane-Camba ex Haroun, Gil-Rodríguez, Díaz de Castro et Prud' homme van Reine. The three species are present just in the lower intertidal where they are under the influence of spray even during low tides (Mercado \& al., 2001). Thus, the zonation pattern of $P$. capillacea, $G$. arbuscula and $G$. canariense in northern Tenerife shores is an appropriate model to test the hypothesis that their heights on the shore may be correlated with their photosynthetic performance.

The objective of this study was to characterize the photosynthetic response of the three species of Gelidiales at two localities on Tenerife and to relate it to the stress of emersion and changes in irradiance levels associated with their different vertical distribution. In particular, the two hypothesis to be tested were: (i) that the time of recovery of photosynthetic activity after desiccation in the selected species (estimated via fluorescence parameters) is higher the lower is the location on the zonation pattern; and (ii) the photoinhibition of the photosynthetic quantum yield around noon is higher the lower is the location in the zonation.

Table 1. ANOVA results for lk and ETRrmax. * the factor 'Species' was tested against 'Species $x$ Run'. 'Species $x$ Site' was removed from the analysis (non-significant, $P=0.27$ ).

\begin{tabular}{|c|c|c|c|c|c|c|c|}
\hline \multirow{2}{*}{ Source of variation } & \multirow[b]{2}{*}{$d f$} & \multicolumn{3}{|c|}{ lk } & \multicolumn{3}{|c|}{ ETRrmax } \\
\hline & & MS & $\boldsymbol{F}$ & $P$ & MS & $F$ & $P$ \\
\hline Species ${ }^{*}$ & 2 & 281.20 & 1.00 & 0.421 & 164184 & 4.50 & 0.064 \\
\hline Site & 1 & 2990.00 & 5.02 & 0.111 & 176026 & 12.60 & 0.038 \\
\hline Run & 3 & 840.23 & 1.41 & 0.392 & 45483 & 3.26 & 0.179 \\
\hline Species $\times$ Site & 2 & 197.43 & 0.78 & 0.499 & 18461 & 1.64 & 0.270 \\
\hline Species $\times$ Run & 6 & 280.36 & 1.11 & 0.451 & 36515 & 3.25 & 0.089 \\
\hline Site $\times$ Run & 3 & 596.03 & 1.26 & 0.293 & 13972 & 1.11 & 0.350 \\
\hline Species $\times$ Site $\times$ Run & 6 & 252.66 & 0.53 & 0.782 & 11242 & 0.89 & 0.505 \\
\hline Error & 96 & 474.03 & & & 12624 & & \\
\hline Total & 119 & & & & & & \\
\hline
\end{tabular}




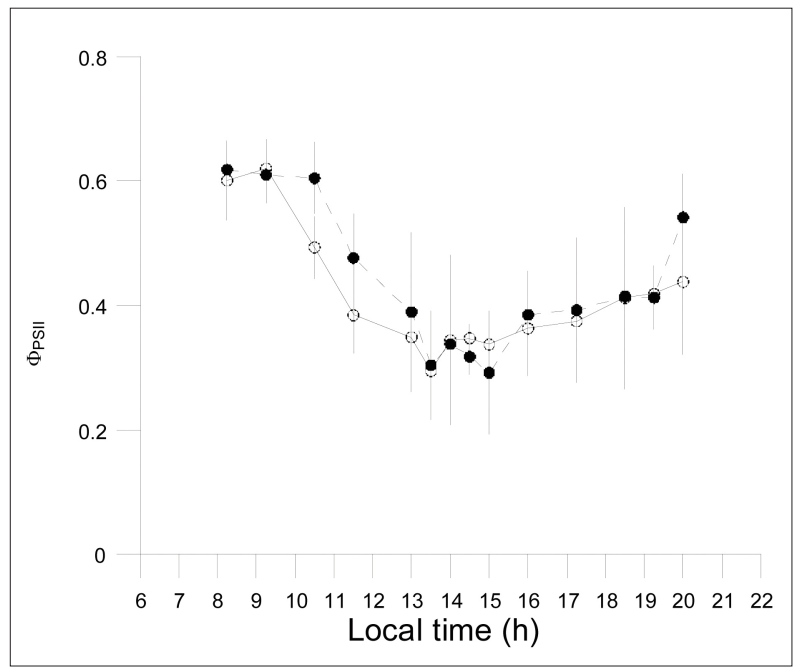

Fig. 1. Daily cycle of photosynthetic quantum yield (ФPSII; dimensionless) in Gelidium canariense. Values are represented as mean \pm SD $(n=5)$ from samples of Puerto de la Cruz (O) and Garachico (•).

\section{Material and methods}

Sampling sites, algal collection and pre-treatment of samples

The Northern coast of Tenerife is very exposed, with frequent periods of intense swell 2 to $3 \mathrm{~m}$ height, and occasional calm periods throughout the year, mainly in spring and summer. During autumn the storms with waves up to $5 \mathrm{~m}$ height are frequent. Water temperature ranges $17^{\circ} \mathrm{C}$ in February to $23^{\circ} \mathrm{C}$ in August.

Two localities separated $30 \mathrm{~km}$ were selected: Puerto de la Cruz (UTM 3675447/3588716) and Garachico (UTM3700288/3590165). Both sites haves similar patterns of marine vegetation, characterized by a belt of blue-green algae in the upper intertidal, a lower caespitose belt dominated by Gelidium pusillum (Stackhouse) Le Jolis, Caulacanthus ustulatus (Merthens ex Turner) Kützing and Ulva rigida C. Agardh, another below mainly of species of the Corallinaceae and Rhodomelaceae and, in the lowest levels, the three species of Gelidiales down to the subtidal (with Pterocladiella capillacea in the upper part, G. arbuscula in the middle and G. canariense in the lowest part) (Gil-Rodríguez \& Wildpret, 1980; Pinedo \& Afonso-Carrillo, 1994).

Thalli free from epiphytes of the three Gelidiales cited above were collected in July 1999. They were transferred to the laboratory in seawater and darkness and kept in $50 \mathrm{~L}$ aquaria at constant temperature (ca. $20^{\circ} \mathrm{C}$ ). Natural solar irradiance was reduced by using plastic mesh that acted as neutral density filters reducing incident PAR to $60-80 \%$ of full sunlight.

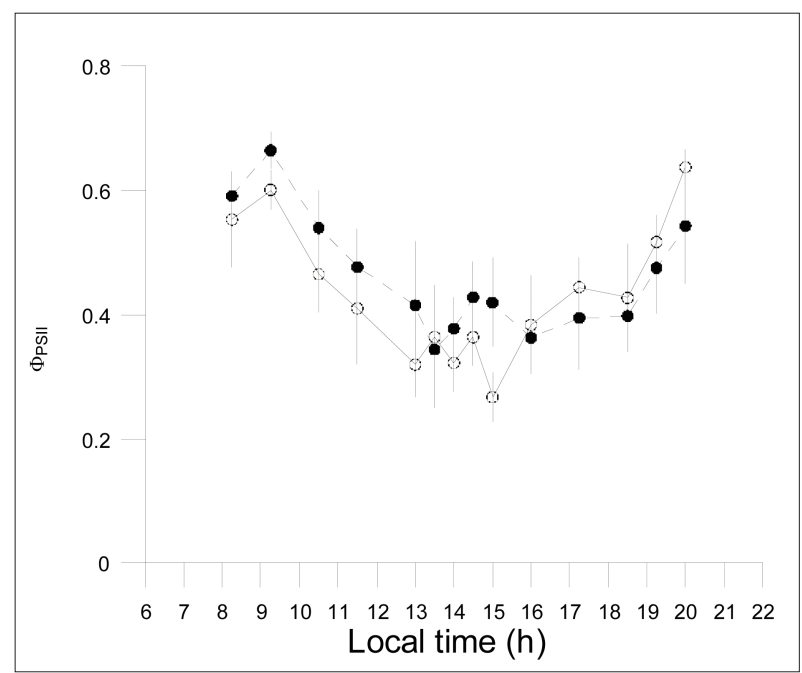

Fig. 2. Daily cycle of photosynthetic quantum yield (ФPsII; dimensionless) in Gelidium arbuscula. Values are represented as mean \pm SD $(n=5)$ from samples of Puerto de la Cruz (O) and Garachico (•).

\section{Experiment A: daily variation in photosynthetic quantum yield}

A system of continuous seawater circulation was designed to keep $10 \mathrm{~L}$ glass aquaria with 10-20 g fresh weight under a constant temperature of $20^{\circ} \mathrm{C}$ during incubations. Measurements of photosynthetic activity were carried out by using a DIVING-PAM (Heinz Walz GmbH, Germany) during a whole daily cycle, from sunset to sunrise. Every hour from sunrise, five

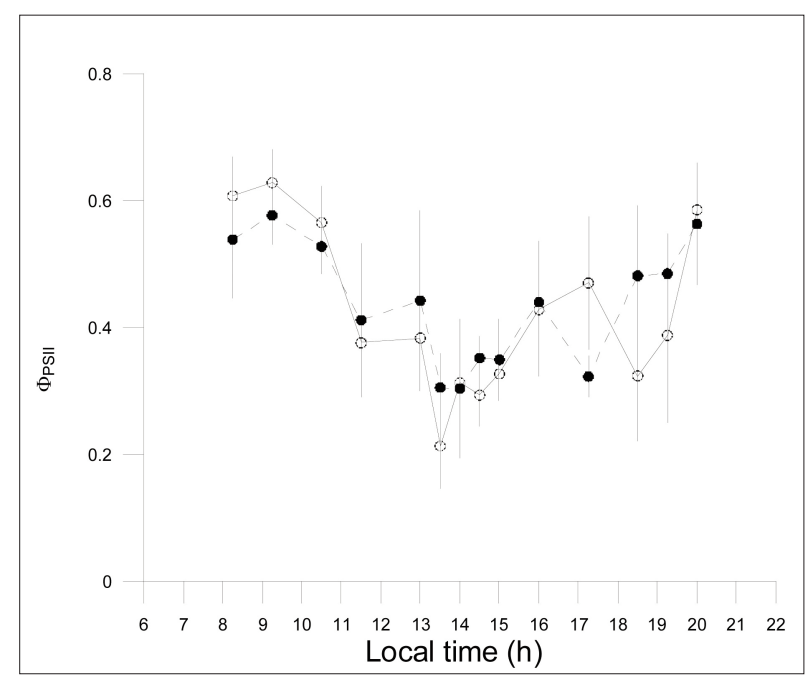

Fig. 3. Daily cycle of photosynthetic quantum yield (ФPsII; dimensionless) in Pterocladiella capillacea. Values are represented as mean \pm SD $(n=5)$ from samples of Puerto de la Cruz (O) and Garachico (•). 


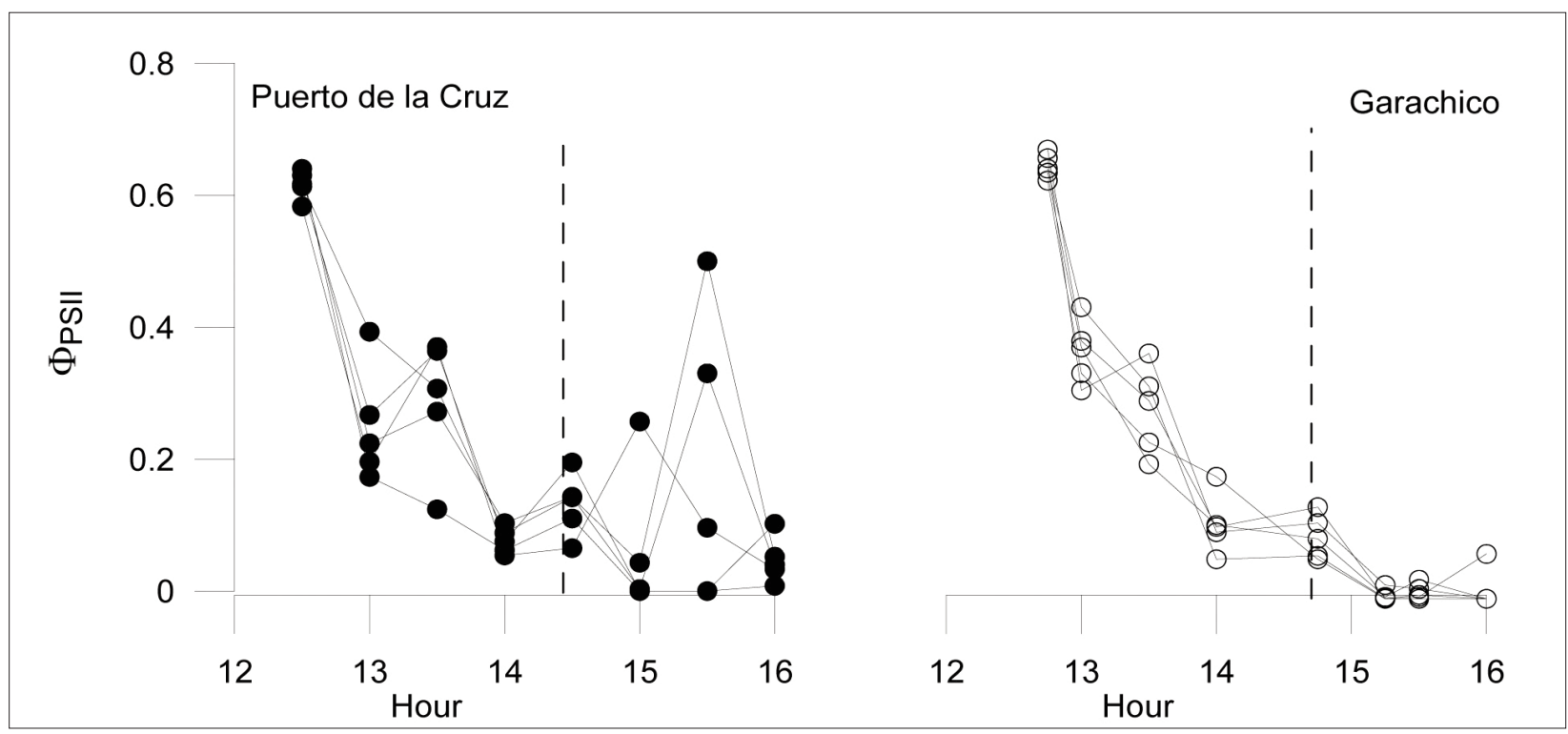

Fig. 4. Photosynthetic quantum yield (ФPsı; dimensionless) of Gelidium canariense from Puerto de la Cruz (left) and Garachico (right) during emersion (values to the left of the vertical broken line) and after resubmergence (values to the right of the broken line). Each line corresponds to a different run.

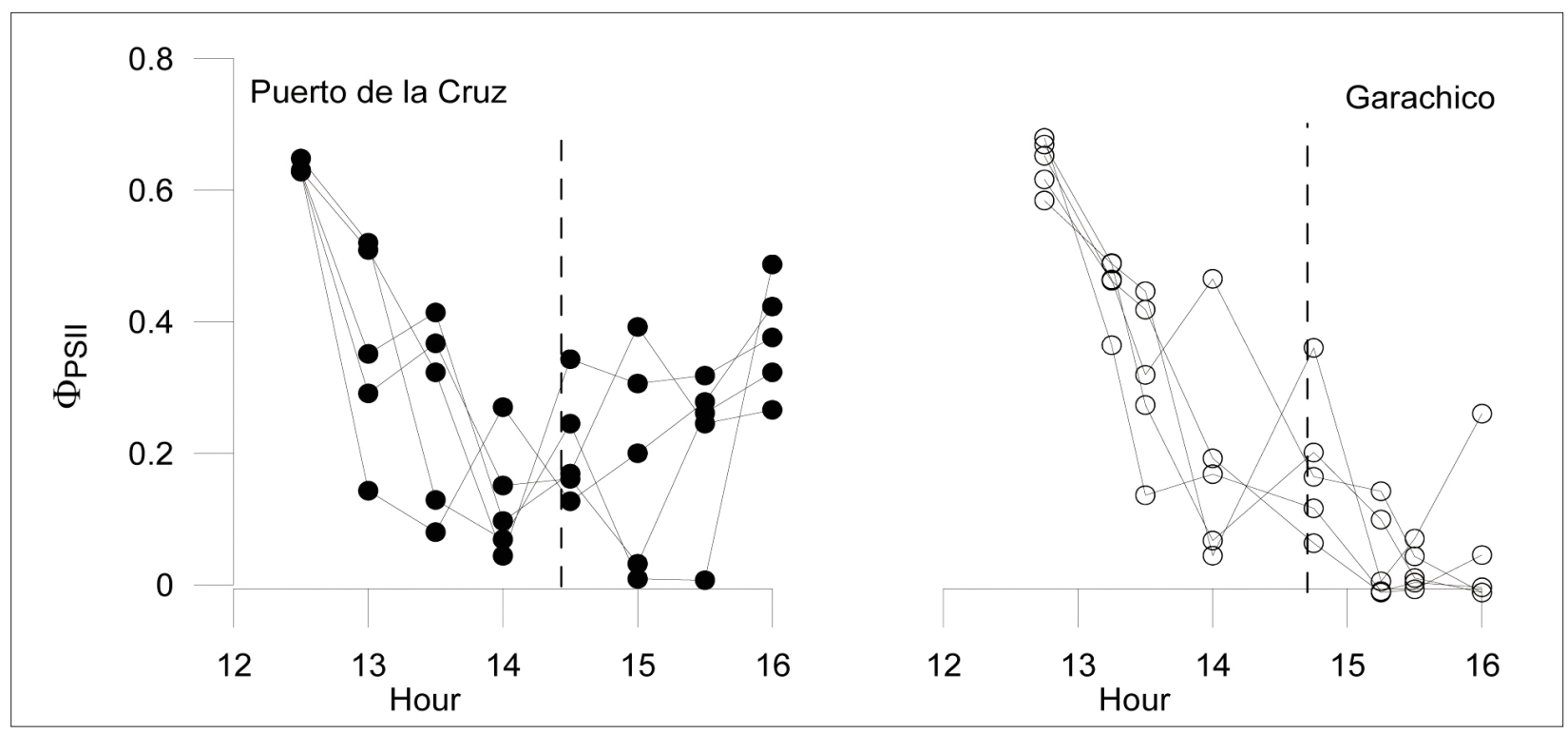

Fig. 5. Photosynthetic quantum yield (ФPsIl; dimensionless) of Gelidium arbuscula from Puerto de la Cruz (left) and Garachico (right) during emersion (values to the left of the vertical broken line) and after resubmergence (values to the right of the broken line). Each line corresponds to a different run.

fronds from the aquaria for each locality and species were selected and photosynthesis was measured. During the central hours of the day $(-2$ to +2 hours around noon) measurements were taking at $30 \mathrm{~min}$ intervals. According to Genty \& al. (1989), photosynthetic activity was estimated from the effective quantum yield of chlorophyll $a$ from photosystem II (ФPSII defined as $\Delta \mathrm{F} / \mathrm{Fm}$ '). The use of the ФPSII values avoid problems derived from the potential differences be- tween absorptances in different species (Franklin \& Badger, 2001) although these differences can be minor in species from the same genus/family and with similar morphology.

Additionally, five fronds per species and locality were exposed to nine levels of increasing $\operatorname{PAR}(0,12,55$, $\left.122,213,317,443,653,889 \mu \mathrm{mol} \mathrm{m}^{-2} \mathrm{~s}^{-1}\right)$ during $45 \mathrm{~s}$ each, after which a saturating pulse was applied and ФPSII values measured. The relative electron transport 


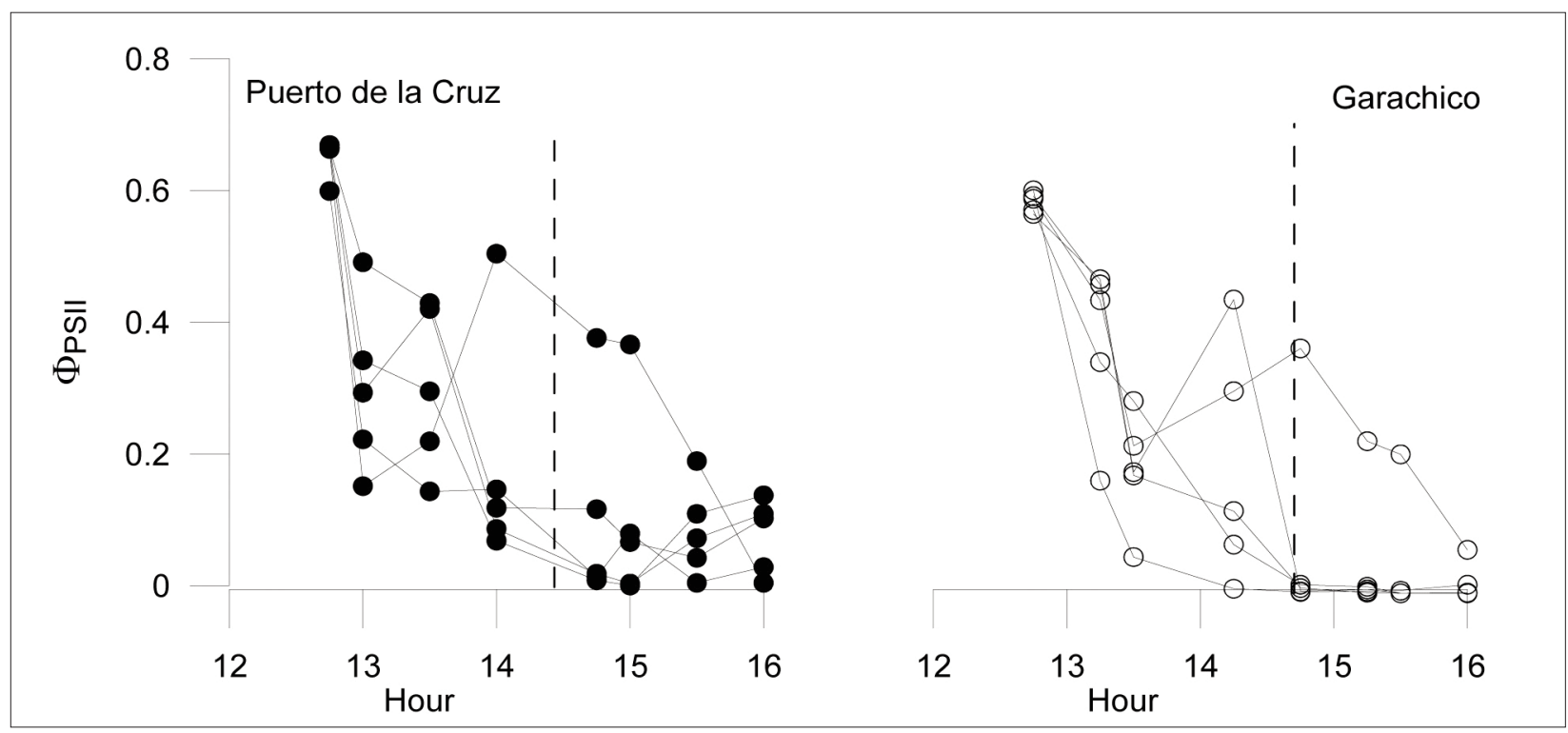

Fig. 6. Photosynthetic quantum yield (ФPsIl; dimensionless) of Pterocladiella capillacea from Puerto de la Cruz (left) and Garachico (right) during emersion (values to the left of the vertical broken line) and after resubmergence (values to the right of the broken line). Each line corresponds to a different run.

rate $(\mathrm{ETRr})$ was computed as PAR $\times$ ФPSII, when ФPSII value was $>0.1$ (Beer \& Axelsson, 2004). The plot of ETRr versus PAR was used to calculate the irradiancesaturated ETR over the saturation point (ETRrmax) and the value of PAR above which ETRrmax was detected (Ik); for this purpose, a non-linear fit to a hyperbolic curve was applied. The experiment was repeated (using different fronds) every $2 \mathrm{~h}$ from sunrise to sunset.

\section{Experiment B: response of photosynthetic performance to desiccation stress and rehydration}

Five fronds from each locality and species were exposed to air by placing them in plastic trays after vigorous shaking to simulate desiccation stress during low tide exposure to air. Fronds were exposed during the hours of highest PAR, since low tides occurred around noon during the experiments. Desiccation stress was estimated from ФPSII measurements at 30 min intervals. Fronds were also weighed to the nearest $\mathrm{mg}$ at the start and at the end of the experiment to calculate the proportion of water loss. After an exposure of $2.5 \mathrm{~h}$ (equivalent to the longest emersion period during spring tides), fronds were rehydrated by submersion in seawater and fluorescence measurements were conducted for $2.5 \mathrm{~h}$ at $30 \mathrm{~min}$ intervals.

\section{Statistical analysis of data}

Data were analyzed using factorial ANOVAs (see results for details on each analysis). All data were analyzed using Statistica for Windows.

\section{Results}

The daily cycle of $\Phi$ PSII in the three species showed a similar pattern: the highest ФPSII values were recorded at the sunrise and decreased abruptly to minimum values (about 50\% lower than those on earlier hours) around solar noon; then, ФРSII increased gradually at the sunset (Figs. 1-3).

A marked reduction in ФPSII was found in the three species when thalli were exposed to air for $2.5 \mathrm{~h}$ simulating emersion conditions (Figs 4-6); however, the highest reduction of ФPSII was recorded in Gelidium canariense (Fig. 4) while Pterocladiella capillacea was the species with the lowest reduction of ФPSII (Fig. 6). The reduction of ФPSII in G. arbuscula after desiccation was intermediate to that of the two other species (Fig. 5). However, the relative water loss was similar in the three species from both localities (overall mean \% water loss $=50.3 \pm 7.4, n=30$ ). The values of ФPSII after $1.5 \mathrm{~h}$ rehydration in G. arbuscula was around 30$50 \%$ than to those measured prior to exposure to air (Fig. 5) while recovery in P. capillacea and G. canariense was lower (Figs. 4, 6).

Photoinhibition was not detected in the ETRr-PAR curves for the three species, and both ETRrmax and Ik values were similar for the three species at both localities (Figs. 7, 8, Table 1). Saturation occurred above $150 \mu \mathrm{mol} \mathrm{m} \mathrm{s}^{-1}$ for the three species, reaching around $500 \mu \mathrm{mol} \mathrm{m} \mathrm{m}^{-2}$ for some samples of G. arbuscula (Fig. 7). 


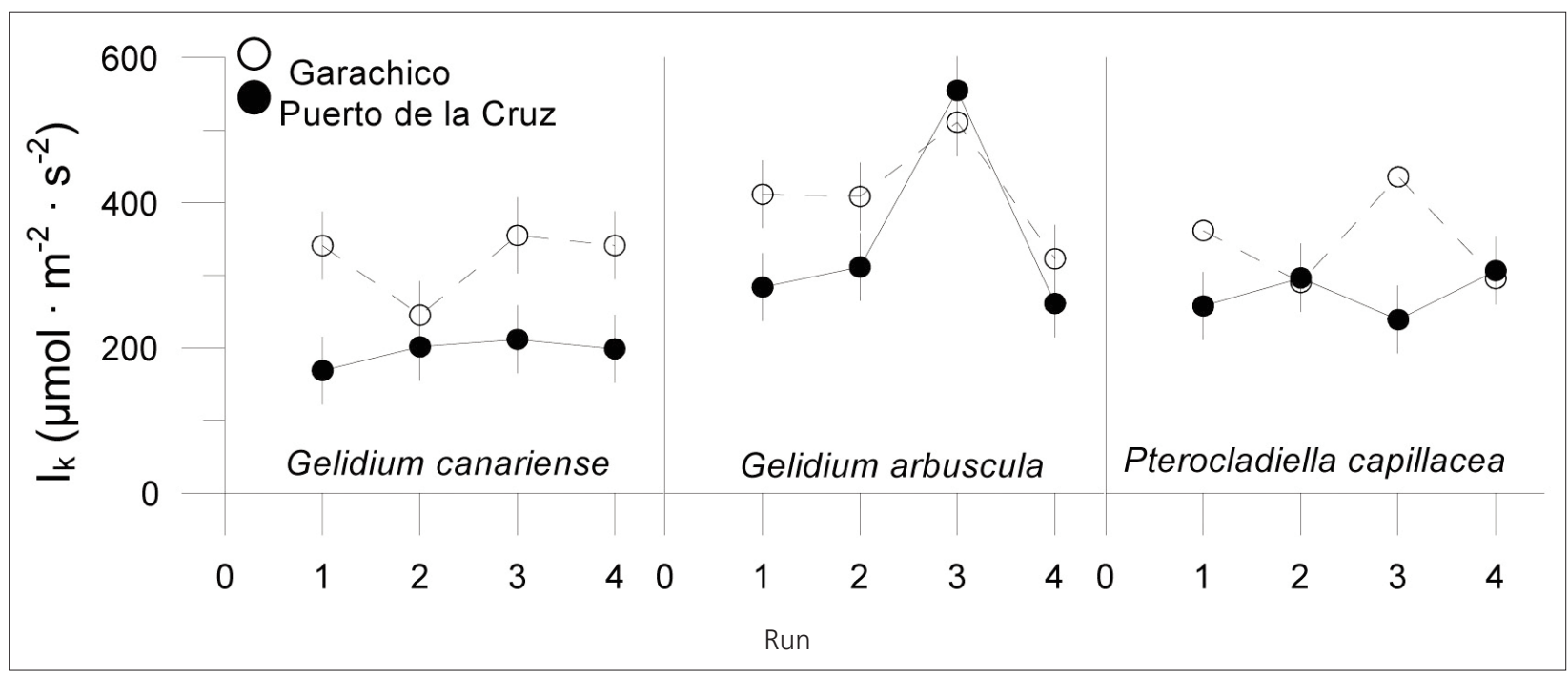

Fig. 7. Values of saturating PAR (Ik) for the three species of Gelidiales from Puerto de la Cruz ( $\bullet$ ) and Garachico (O). 'Run' refers to the time period (UTC+2) when the measurements for the curves where taken (1: from 10 to 11 a.m.; 2: from 12 to 13; 3: from 14 to 15; 4: from 16 to 17).

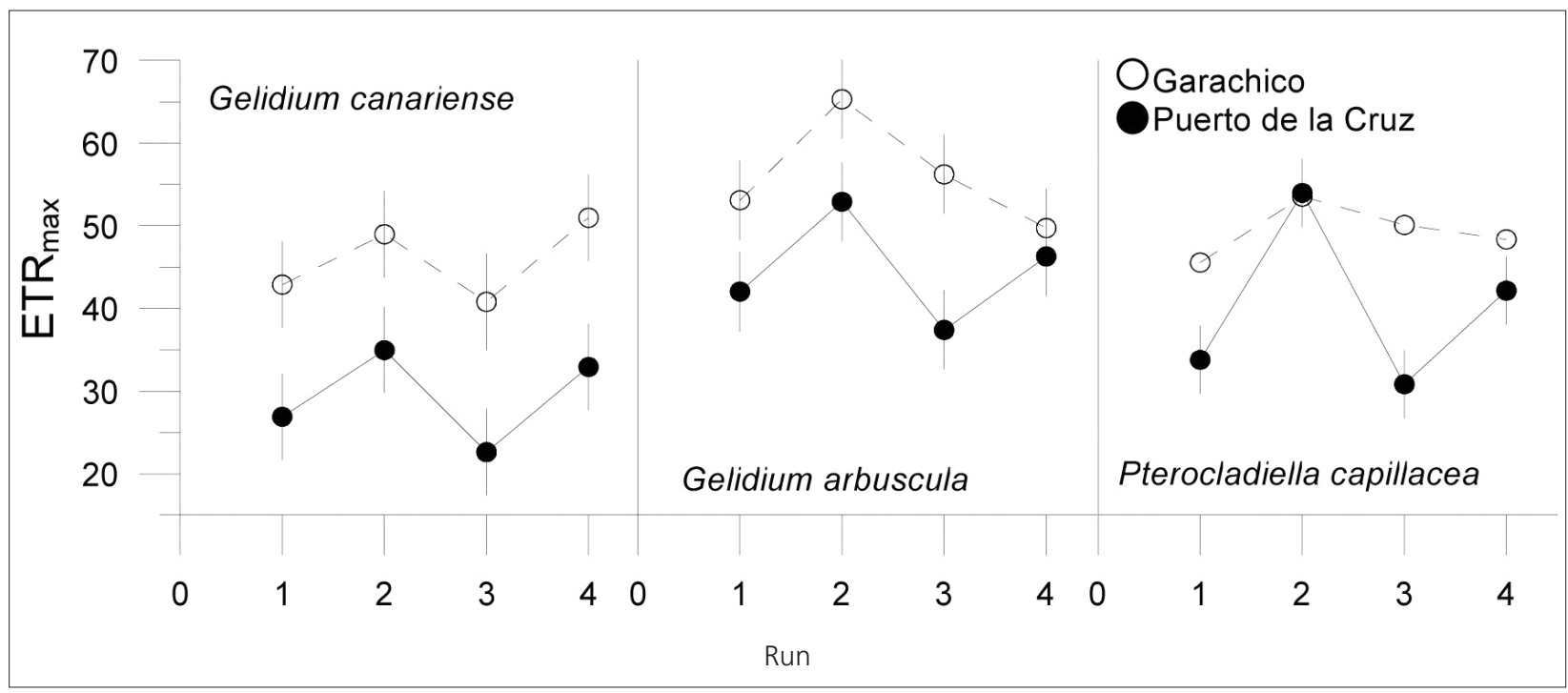

Fig. 8. Values of irradiance-saturated, relative electron transport rate (as ETRrmax) for the three species of Gelidiales from Puerto de la Cruz (•) and Garachico (O).'Run' refers to the time period (UTC+2) when the measurements for the curves where taken (1: from 10 to 11 a.m.; 2 : from 12 to 13 ; 3 : from 14 to $15 ; 4$ : from 16 to 17 ).

\section{Discussion}

The presence of several species of Gelidiales in contiguous altitudinal belts is a common feature of many temperate coasts (Santelices, 1991) and it has been suggested that this pattern indicates close similarities among species with respect to environmental tolerance (Santelices, 1991; Montalva \& Santelices, 1981). In the Gelidium-dominated lower shore in N Spain, irradiance did not appear as a critical factor for photosynthesis (Rico, 1991), but different Gelidium species showed different saturation values $\left(\mathrm{I}_{\mathrm{k}}\right)$ which could be related to their altitudinal position on the shore (Rico \& Fredriksen, 1996). This is not the case with the three Gelidiales from Teneriffe, which exhibited similar patterns of both photoinhibition of ФPSII along the daily cycle and ETRr-PAR curves, and it has been shown that ETR values can be used to estimate photosynthesis in Gelidium species since they compare well with photosynthetic estimations using, for instance, $\mathrm{O}_{2}$ electrodes (Beer \& Axelsson, 2004; Franklin \& Badger, 2001; Silva \& al., 1998). 
Since the photosynthetic response under standard conditions did not differ between species, the position on the shore could be explained by negative effects of desiccation on net photosynthesis as it has been demonstrated in fucoids (Williams \& Dethier, 2005). Desiccation occurs during low tide almost every day, its length determined by the duration of the tide. Gelidium sesquipedale from Asturias, a lower intertidal species, showed a higher reduction in net photosynthesis after exposure to air (Rico \& Fredriksen, 1996), and an exposure longer than $2 \mathrm{~h}$ caused a negative net production, thus photosynthesis was overcome by respiration. The same occurred for G. canariense, the species lowest on the shore in Teneriffe, which was more affected by desiccation and also recovered to a lesser degree after rehydration. Recovery of photosynthesis after emersion is one of the major factors explaining the upper limits of seaweeds in the intertidal (Dring \& Brown, 1982). It has been suggested that both tolerance to sustain photosynthesis under desiccation and reduction in the rate of water loss can help intertidal species to tolerate longer emersion periods (Oates \& Murray, 1983). This could be the case with the two species located upper in the shore in our study: G. arbuscula is morphologically similar to G. pulchellum, which showed a reduced rate of water loss after emersion periods of more than $3 \mathrm{~h}$ (Rico \& Fredriksen, 1996), while P. capillacea showed a rapid recovery after rehydration. All three species were able to recover after exposure to periods shorter than $2.5 \mathrm{~h}$ which suggests that small differences in the recovery rate could explain upper tolerance limits on the shore. Duration of natural exposure to air in intertidal seaweeds determines the degree of drying, but during these periods it is the rate of drying which explains the stress (Hunt \& Denny, 2008). Thus, tolerance to desiccation (as opposed to the desiccation stress) and the light environment (Mercado \& al., 2001) are the main factors to explain the zonation pattern of these three species in the coast of Teneriffe. Apart from the obvious effect of reduced irradiance levels during high tides affecting photosynthetic production, exposure to full solar radiation during low tides can also affect photosynthetic performance, mainly at noon (Gómez \& Figueroa, 1998). Accordingly, $P$. capillacea showed the most intense noon-depleted ETRr rate, while showing intermediate values of the photosynthetic parameters. Gelidium arbuscula did not show noon depletion in ФPSII and showed the highest values both in ETRrmax and in Ik, and G. canariense showed a moderate reduction in DPSII at noon but not so high values in the photosynthetic parameters. It could be concluded that the upper species, $P$. capillacea, is adapted to exposure to air and high irradiance levels during emersion by reducing ФPSII and showing fast recovery after rehydration, while G. arbuscula is able to reduce water loss due to its compact morphology, which may also produce frond shading and so attenuate the effect of high irradiance, and 'clump' morphology represents a significant advantage to reduce water loss in central portions of the thallus (Hunt \& Denny, 2008). Differences in zonation between sites are intriguing, although between site variation has been reported before and explained by a multiarray of factors other than exposure (Williams \& Dethier, 2005). Further studies will be needed to fully assess these additional factors which may explain small scale differences in the zonation pattern, although small topographic differences may produce differences also in the local light regime.

\section{Acknowledgements}

Personnel from the Centro Oceanográfico de Canarias - Instituto Español de Oceanografía de Canarias (IEO), gave support to experiments. The contribution of J.M. Cejas is especially acknowledge.

\section{References}

Beer, S. \& L. Axelsson. 2004. Limitations in the use of PAM fluorometry for measuring photosynthetic rates of macroalgae at high irradiances. European Journal of Phycology 39: 1-7.

Bischof, K., Gómez, I., Molis, M., Hanelt, D., Karsten, U., Lüder, U., Roleda, M.Y., Zacher, K. \& Wiencke, C. 2006. Ultraviolet radiation shapes seaweed communities. Reviews in Environmental Science and Biotechnology 5: 141-166.

Chapman, A.R.O. 1973. A critique of prevailing altittudes towards the control of seaweed zonation on the seashore. Botanica Marina 16: 80-82.

Chapman, A.R.O. 1974. The ecology of macroscopic marine algae. Annual Review of Ecology and Systematics 5: 65-80.

Dring, M.J. \& Brown, F.A. 1982. Photosynthesis of intertidal brown algae during and after periods of emersion: a renewed search for physiological causes of zonation. Marine Ecology Progress Series 8: 301-308.

Flores-Moya, A., Gómez, I., Viñegla, B., Altamirano, M., PérezRodríguez, E., Maestre, C., Caballero, R. \& Figueroa, F.L. 1998. Effects of solar radiation on the endemic Mediterranean red alga Rissoella verruculosa: photosynthetic performance, pigment content and the activities of enzymes related to nutrient uptake. New Phytologist 139: 673-683.

Franklin, L.A. \& Badger, M.R. 2001. A comparison of photosynthetic electron transport rates in macroalgae measured by pulse amplitude modulated chlorophyll fluorometry and mass spectrometry. Journal of Phycology 37: 756-767.

Genty, B., Briantais, J.M. \& Baker, N.R. 1989. The relationship between the quantum yield of photosynthetic electron transport and quenching of chlorophyll. Biochimica et Biopbysica Acta 990: 87-92.

Gevaert, F., Creach, A., Davoult, D., Holl, A.-C., Seuront, L. \& Lemoine, Y. 2002. Photo-inhibition and seasonal photosynthetic performance of the seaweed Laminaria saccharina during a simulated tidal cycle: chlorophyll fluorescence measurements and pigment analysis. Plant, Cell and Environment 25: 859-872. 
Gil-Rodríguez, M.C. \& Wildpret, W. 1980. Contribución al estudio de la vegetación ficológica marina del litoral canario. Aula de Cultura Excmo. Cabildo Insular de Tenerife.

Gómez, I. \& Figueroa, F.L. 1998. Effects of UV stress on chlorophyll fluorescence kinetics of intertidal macroalgae from southern Spain: a case study in Gelidium species. Journal of Applied Phycology 10: 285-294.

Hall, D.O. \& Rao, K.K. 1999. Photosynthesis. Cambridge University Press, Cambridge.

Hanelt, D., Huppertz, K. \& Nultsch, W. 1993. Daily courses of photosynthesis and photo-inhibition in marine macroalgae investigated in the laboratory and field. Marine Ecology Progress Series 97:31-37.

Hunt, L.J.H. \& Denny, M.W. 2008. Desiccation protection and disruption: a trade-off for an intertidal marine alga. Journal of Phycology 44: 1164-1170.

Huppertz, K., Hanelt, D. \& Nultsch, W. 1990. Photo-inhibition of photosynthesis in the marine brown alga Fucus gardneri as studied in field experiments. Marine Ecology Progress Series 66: 175 182.

Lewis, J.R. 1964. The Ecology of Rocky Shores. English University Press, London.

Mercado, J.M., Niell, F.X. \&. Gil-Rodríguez, M.C. 2001. Photosynthesis might be limited by light, not inorganic carbon availability, in three intertidal Gelidiales species. New Phytologist 149: 431-439.

Montalva, S. \& Santelices, B. 1981. Interspecific interference among species of Gelidium from Central Chile. Journal of Experimental Marine Biology and Ecology 53: 77-88.

Oates, B.R. \& Murray, S.N. 1983: Photosynthesis, dark respiration and dessication resistance of the intertidal seaweeds Hesperophycus harveyanus and Pelvetia fastigiata f. gracilis. Journal of Phycology 19: 371-380.
Pérès, J.M. 1982. Zonations and organismic assemblages. In: Kinne, O. (ed.), Marine Ecology, Vol. V, Ocean management, Part 1. Wiley, Chichester, pp. 9-576.

Pinedo, S. \& J. Afonso-Carrillo. 1994. Distribución y zonación de las algas marinas bentónicas en Puerto de la Cruz, Tenerife. Vieraea 23: 109-123.

Rico, J.M. 1991. Field studies and growth experiments on Gelidium latifolium from Asturias (N Spain). Hydrobiologia 221: 67-75.

Rico, J.M. \& Fredriksen, S. 1996. Effects of environmental factors on net photosynthesis and growth of intertidal species of the genus Gelidium (Gelidiaceae, Rhodophyta) in northern Spain. Scientia Marina 60: 265-273.

Santelices, B. 1991. Production ecology of Gelidium. Hydrobiologia 221/222: 31-44.

Silva, J., Santos, R., Serodio, J. \& Melo, R.A. 1998. Light response curves for Gelidium sesquipedale from different depths, determined by two methods: $\mathrm{O}_{2}$ evolution and chlorophyll fluorescence. Journal of Applied Phycology 10: 295-301.

Stephenson, T.A. \& Stephenson. A. 1972. Life Between TideMarks on Rocky Shores. W.H. Freeman, USA.

Wiencke, C., Gómez, I., Pakker, H., Flores-Moya, A., Altamirano, M. Hanelt, D., Bischof, K. \& Figueroa, F.L. 2000. Impact of UV-radiation on viability, photosynthetic characteristics and DNA of brown algal zoospores: implications for depth zonation. Marine Ecology Progress Series 197: 217-229.

Williams, S.L. \& Dethier, M.N.. 2005. High and dry: variation in net photosynthesis of the intertidal seaweed Fucus gardneri. Ecology 86: 2373-2379.

Associate Editor: A. Flores Received: 27-XII-2010 Accepted: 10-II-2011 